\title{
CORUNDUM INCLUSIONS IN DIAMONDS - DISCRIMINATORY CRITERIA AND A CORUNDUM COMPOSITIONAL DATABASE
}

\author{
Mark T. Hutchison ${ }^{1}$, Peter H. Nixon ${ }^{2}$ and Simon L. Harley ${ }^{3}$ \\ ${ }^{1}$ Lunar and Planetary Laboratory, University of Arizona U.S.A.; ${ }^{2}$ University of Leeds, U.K.; ${ }^{3}$ University of Edinburgh, U.K.
}

\section{INTRODUCTION}

Corundum has been reported previously as occurring as syngenetic inclusions in diamonds from the alluvial deposits of tributaries of the Rio Aripuanã, Juina, Brazil (Watt et al., 1994; Harte et. al., 1999; Hutchison et al., 2001). Here we expand on the database of ruby and white corundum inclusions from Juina and present the first recorded occurrence of sapphire as an inclusion in diamond.

The identification of corundum as a syngenetic phase within diamond corroborates previous empirical observations of corundum associations with alluvial diamonds made in Brazil and elsewhere (Tremblay, pers. comm. 2002) and identifies corundum as a potential indicator mineral for diamond prospectivity. In order for corundum to be useful for this purpose however, means must be established to isolate corundums with a diamond affinity from those from other mantle and crustal sources.

Despite the low abundances of trace elements in corundums, they do contain measurable quantities. Furthermore, because the $\mathrm{Al}_{2} \mathrm{O}_{3}$ structure contains sites appropriate for hosting high field strength elements and a number of transition metals which are fractionated in widely differing fashions in different mantle and crustal settings, trace elements could theoretically provide a means of identifying corundums grown in different settings. As corundum is resistant to weathering and is often observed in heavy mineral separates, the propensity exists to use corundum compositions as an indicator of geological origin and thus an exploration tool.

Here we present preliminary discriminatory tools for corundum genesis on the basis of minor and trace element data. In achieving this, and as trace element data for corundums occurs sparsely in the literature (e.g. Schreyer et al., 1981; Kerrich et al., 1987), we have collected and analysed corundums from a variety of source environments in addition to inclusions in diamonds. Samples associated with granitic emplacement were procured in addition to those from amphibolite-facies and granulite-facies rocks, and various synthetic origins. Finally, carmine coloured corundum grains from kimberlite drill cores from Saskatchewan, Canada were included in the sample set. In order to obtain absolute concentration data, it has also been necessary to fabricate highly aluminous glass standards for use in SIMS analyses.

\section{CORUNDUM INCLUSIONS IN DIAMOND}

Corundum-occluding diamonds were collected from alluvial gravels from the Juina district of Mato Grosso, Brazil. The samples came from the Rio Vinte e Um and the Rio Cinta Larga and its tributories the Rio Mutum, Igarapé Porcão, Rio Juininha and Rio Juina-Mirim. Kimberlitic sources of these diamonds have not so far been identified, however anomalous electromagnetic signatures and an abundance of kimberlitic ilmenites in associated gravels suggests diamonds were recovered close to their source rocks. The corundum inclusions were recovered from their host diamonds by fracturing in a purpose built steel anvil (Hutchison, 1997).

Three inclusions of ruby were recovered with one 60 $\mu \mathrm{m}$ grain being a composite with a high $(10 \mathrm{wt} \%) \mathrm{Al}_{2} \mathrm{O}_{3}$ pyroxene and occurring within the same diamond as a syngenetic inclusion of ferropericlase $((\mathrm{Mg}, \mathrm{Fe}) \mathrm{O})$. Additionally, a single $300 \mu \mathrm{m}$ intense blue sapphire inclusion and two white corundums were recovered. This is the first recorded occurrence of sapphire as an inclusion in diamond.

The occurrence of ruby within the same diamonds as high alumina pyroxene and their association with ferropericlase suggest that the ruby inclusions have an origin within the lower mantle. Specifically, phase relations with aluminous pyroxene (originally perovskite structured) place their origin within a depth range of $\sim 720-820 \mathrm{~km}$ depending on ambient temperature (Hutchison et al. 2001).

White corundum and the single 300-micron sapphire inclusion were not associated with other mineral grains and hence their depth of origin is unknown. However inclusion study and measurement of nitrogen characteristics (Hutchison et al., 1999) in run-of mine production diamonds are compatible with the majority 
of diamonds being of transition-zone and lower-mantle origin.

\section{ADDITIONAL CORUNDUMS}

Carmine coloured corundums PHN6087/20 (PHNc) were recovered from kimberlite drill cores from Forte à la Corne, Canada. Given that probable lower mantle diamonds have been recovered from Lac de Gras, Canada, as evidenced by inclusions of ferropericlase (Davies et al., 1999) it was considered pertinent to question whether the Forte à la Corne samples had a deep mantle flavour. These samples were also of interest because of their unusual colouration and compositional zonation. The carmine coloured corundum grains were recovered from heavy mineral separation of in excess of $300 \mathrm{~kg}$ of kimberlite borehole cores from the Forte à la Corne kimberlite field, Saskatchewan, Canada. The separation procedure involved jaw and roller crushing, $\mathrm{HCl}$ acidification and screening, drying at $105-110^{\circ} \mathrm{C}$, electromagnetic separation and heavy mineral separation using bromoform and clerici solution - thallium formate. Separation and handpicking was overseen by Kevin Leahy (Exploration Consultants Ltd.), Oleg von Knorring (deceased) and P.H. Nixon.

Samples obtained from University of Arizona Mineral Museum consisted white corundum from the Rockford Granite, Tallapoosa County, Alabama (3640), an s-type felsic plutonic suite described in Drummond et al. (1988) and granite intruding felsite dyke hosted light brown corundum from the Sacatan Mountains, Pinal County, Arizona (12976 of the type recorded in Larrabee, 1969). Additionally, claret coloured corundums var. ruby associated with clinozoisite from Kenya (9997) and from high-grade Proterozoic orthoamphibolites of the Bamble Sector, Froland, Arundel, Norway (1855 of the type described by Vissor and Senior, 1990 and Nijland et al., 1993) were obtained from the same source.

Claret coloured corundum associated with clinozoisite from Tanzania (PHNz) was provided from the collection of P.H. Nixon in addition to synthetic corundum (SYNCOR) manufactured commercially by the reaction of chromite with metallic $\mathrm{Al}$ to form $\mathrm{Cr}$ corundum plus $\mathrm{Cr}$ metal and catalysed with undisclosed $\mathrm{Ca}$ and $\mathrm{K}$-bearing compounds.

High-grade granulite-facies hosted samples from Japan and Antarctica were included from the collection of S. L. Harley. The Japanese sample (HIGO) is from Zone
D of the Higo Mesozoic metamorphic belt which is part of the high $\mathrm{T} /$ low $\mathrm{P}$ Ryoke Belt in Kyushu. The sample is from a high temperature reaction zone intimately associated with an ultramafic sliver interpreted as being a high temperature intrusion $\left(800^{\circ} \mathrm{C}\right.$, 5-6kbar, Osanai et al., 1996). The metasomatised corundum is associated with pale blue Mg-sapphirine, spinel and altered plagioclase. Sample 91-38 (Harley, 1998) is from a garnet sillimanite phlogopite gneiss where corundums are surrounded by coronas of sillimanite and sapphirine and cordierite and constitutes a metasomatic zone between mafic and pelitic rocks hosted in Archaean (2800 Ma) orthogneisses. The remaining samples are all from the Taynaya supracrustals of the Vestfold Hills, Antarctica (Snape and Harley, 1996). Samples (65178, 65305 and SH-9296) all come from what are termed 'Type II' white sugary textured boudin cores containing assemblages of K-feldspar, corundum, sapphirine and sillimanite. The protoliths are thought to be pyrophyllite or muscovite bearing rocks, probably claystones of hydrothermally altered clay / sericite / chlorite rocks and are hosted in 2520-2500 Ma TTG suite orthogneisses or as rafts in 2500-2486 Ma monzodioritic gneisses. Sample 65305 was obtained from locality B of Harley (1993), sample 65178 from locality A and sample SH-9296 from within Crooked Lake Gneisses approximately $3 \mathrm{~km}$ to the northwest.

A synthetic ruby (BURM), believed to be from Burma and obtained in Kuala Lumpur was obtained for study.

\section{ANALYTICAL METHODS}

Major and minor element concentrations were obtained by conventional means by electron probe microanalysis (EPMA) at the Universities of Edinburgh and Arizona.

To provide suitable secondary ion mass spectrometry (SIMS) standardisation, homogeneous La-Aluminate glass doped with twenty elements was manufactured using levitation laser vitrification and characterised by laser ICPMS and EPMA. La Aluminate glass was made as $\mathrm{La}_{9} \mathrm{Al}_{15} \mathrm{XO}_{36}$ where the $\mathrm{X}$ refers to trace elements introduced as 2000 ppm atomic. Final concentrations of doped elements were found by ICPMS to typically be lower than these amounts due to volatilization during the vitrification process however EPMA analyses showed standards to exhibit good homogeneity. The La / Al ratio of 3/5 employed corresponds to the $\mathrm{La}, \mathrm{Al}$ eutectic. 
Absolute concentrations of twenty-one elements were measured by SIMS. Measurements conducted on all corundum inclusions from Juina diamonds with the exception of the composite grain with aluminouspyroxene which proved too small to analyse. Analyses were performed using the Cameca ims-4f of the University of Edinburgh / N.E.R.C. using the duoplasmatron $\mathrm{O}^{-}$source. An $8 \mathrm{nA}$ beam current was used with a contrast diaphragm of $150 \mu \mathrm{m}$, field aperture of 1 and an energy offset of $80 \mathrm{~V}$. Masses ${ }^{40} \mathrm{Ca},{ }^{48} \mathrm{Ti},{ }^{52} \mathrm{Cr}$, ${ }^{56} \mathrm{Fe},{ }^{58} \mathrm{Ni},{ }^{69} \mathrm{Ga},{ }^{74} \mathrm{Ge},{ }^{85} \mathrm{Rb},{ }^{88} \mathrm{Sr},{ }^{89} \mathrm{Y},{ }^{90} \mathrm{Zr},{ }^{93} \mathrm{Nb}$ and ${ }^{208} \mathrm{~Pb}$ were measured as single positively charged ions, backgrounds were measured at mass 130.5 and high mass standardisation was made on ${ }^{197} \mathrm{Au}$. Because of the high abundance of $\mathrm{Al}$ and the risk of damage to the electron multiplier, this element was measured at mass 13.5 corresponding to $\mathrm{Al}^{2+}$. A ratio of $\mathrm{Al}^{2+}$ to $\mathrm{Al}^{+}$of 0.0911 was obtained for standardisation. All subsequent ion-probe analyses were made on the Cameca ims-3f of the State University of Arizona using the duoplasmatron $\mathrm{O}^{-}$source at $12.5 \mathrm{kV}$. Contrast aperture of $150 \mu \mathrm{m}$, field aperture of $1800 \mu \mathrm{m}$ and energy offset of $75 \mathrm{~V}$ were employed.

\section{RESULTS}

Table 1 summarises the results of concentrations of minor and trace elements analysed using EPMA and SIMS where applicable. In terms of minor elements, the sapphire is characterized by $\mathrm{Fe}$ as the dominant minor element whereas red corundums are dominated by $\mathrm{Cr}$; the blue component of ruby spectra being attributed also to a presence of significant Fe. For white corundums, $\mathrm{Ti}$ and $\mathrm{Fe}$ concentrations are observed to both be high; greater than $0.4 \mathrm{wt} \%$ oxide. The most striking observation was that corundums from similar geological settings showed very similar compositions and were easily distinguishable from those of differing origin. Irrespective of locality, rubies from Norwegian, Tanzanian and Kenyan amphibolite-facies rocks were compositionally indistinguishable. Similarly corundums from metasomatised zones associated with contact metamorphism from Arizona and Japan were very similar; particularly characterised by unusually high abundance of mobile $\mathrm{Y}, \mathrm{Zr}$ and $\mathrm{Nb}$.

The Juina sapphire inclusion exhibited much larger ratios of $\mathrm{Ga}$ and $\mathrm{Ge}$ to HFSE elements compared to otherwise similar corundums. White corundum inclusions are particularly rich in $\mathrm{Ge}$, exhibiting up to $\sim 50,000 \mathrm{ppm}$ for one analysis. Ruby inclusions are distinguished from synthetic rubies in particular by their homogeneity and $\mathrm{Ca} / \mathrm{Ti}$ ratios less than unity and from otherwise similar corundums from amphibolites by an order of magnitude higher $\mathrm{Ni}$.

At least two distinct compositional zones are identified by BSE imaging and measurements of elemental concentrations in carmine corundums from Forte à la Corne. These can broadly be classified as high and low$\mathrm{Ca}$. Concentrations in these zones are found to be indistinguishable from similar zones observed in SYNCOR synthetic corundum. Furthermore, with the exception of slightly more $\mathrm{Fe}$ and less $\mathrm{Si}$, similar concentrations of all elements measured were seen in synthetic gem ruby BURM. It is therefore concluded that Forte à la Corne corundums are likely to be some form of contaminant introduced during the drilling process.

\section{SUMMARY AND CONCLUSIONS}

As corundum is shown to occur syngenetically with diamond and its hardness and chemical stability lend it to survival in conditions more extreme than other diamond-associated minerals, potential exists for corundum to be used as a tool for diamond prospectivity. We have demonstrated with a small sample set that minor and trace element compositions of corundum show strong similarities amongst corundums from related geological yet varied geographical settings. At the same time, identifiable differences occur between corundums from differing geological settings and in particular corundum inclusions in diamonds are shown to be distinguishable from other samples. In this case, all inclusion corundums; namely sapphire, ruby and white corundum are particularly identifiable by high $\mathrm{Ni}$ concentrations in excess of 1000 ppm; an order of magnitude greater than $\mathrm{Ni}$ in other samples.

As corundum is a common accessory phase in rocks from a range of geological settings, it is envisaged that corundums with a diamond association may be significantly outnumbered by those from non-diamond bearing country rocks. It is possible however that $\mathrm{Ni}$ concentrations may often be high enough to be detectable by rapid energy dispersive spectrometry (EDS) techniques such as being developed by Australia's CSIRO. It is therefore envisaged that corundum could be used as a useful tool to compliment conventional indicator mineral techniques. 
Table 1: Minor and Trace Element Concentrations in Corundums

\begin{tabular}{|c|c|c|c|c|c|c|c|c|c|}
\hline Sample & Ruby & Sapphire & White & $\mathrm{PHNc}$ & Syncor & BURM & PHNc & Syncor & 3640 \\
\hline Notes & Juina & Juina & Juina & Low-Ca & Low-Ca & & High-Ca & High-Ca & \\
\hline $\mathrm{n}$ & 3 & 2 & 3 & 1 & 1 & 2 & 1 & 1 & 3 \\
\hline $\mathrm{Mg}$ & - & - & - & 1056 & 1122 & 397.8 & 51590 & 65400 & 7889 \\
\hline $\mathrm{Si}$ & - & - & - & $0.006^{*}$ & $0.007^{*}$ & 6561 & $0.059^{*}$ & $0.056^{*}$ & 24100 \\
\hline $\mathrm{Ca}$ & 6464 & 206.7 & $0.01^{*}$ & 585.4 & 226.1 & 351.8 & 95390 & 25230 & 483.0 \\
\hline $\mathrm{Ti}$ & 17730 & 30220 & $0.44^{*}$ & 223.3 & 281.8 & 1897 & 1080 & 1528 & 81190 \\
\hline $\mathrm{Cr}$ & $8.62^{*}$ & 714.5 & 29270 & $3.409^{*}$ & $1.274^{*}$ & $0.450^{*}$ & $25.12^{*}$ & $6.081^{*}$ & 80600 \\
\hline $\mathrm{Mn}$ & - & - & - & 77.23 & 49.92 & 10.71 & 582.7 & 1704 & 43.47 \\
\hline $\mathrm{Fe}$ & $0.49^{*}$ & $0.60^{*}$ & 94140 & 47.38 & 29.01 & 401.6 & 9945 & 506.7 & $0.887^{*}$ \\
\hline $\mathrm{Ni}$ & 3993 & 2701 & 9377 & 76.11 & 24.92 & 23.74 & 881.2 & 127.1 & 58.75 \\
\hline $\mathrm{Cu}$ & - & - & - & 638.2 & 187.0 & 580.7 & 960.3 & 344.3 & 3373 \\
\hline $\mathrm{Ga}$ & 2870 & 13260 & 772.8 & 99.52 & 106.7 & 93.81 & 481.5 & 824.0 & 1543 \\
\hline $\mathrm{Ge}$ & 8115 & 14470 & 20210 & 420.36 & 298.2 & 473.16 & 133.5 & 489.0 & 5840 \\
\hline $\mathrm{Rb}$ & 1.24 & 0.52 & 19.44 & - & 0.54 & 0.26 & 20.43 & 25.09 & 0.97 \\
\hline $\mathrm{Sr}$ & 6.78 & 0.73 & 6159 & 1.10 & 0.29 & 1.67 & 285.7 & 582.4 & 14.62 \\
\hline$Y$ & 0.96 & 1.27 & 2042 & 1.18 & - & 0.80 & 0.94 & 6.11 & 0.17 \\
\hline $\mathrm{Zr}$ & 35.40 & 1.02 & 108535 & 1.16 & 3.20 & 3.18 & 4.51 & 244.6 & 1.06 \\
\hline $\mathrm{Nb}$ & 9.24 & 0.40 & 297.6 & 1.99 & 0.73 & 1.84 & 3.23 & 4.77 & 2.10 \\
\hline Mo & - & - & - & 16.33 & 26.57 & 17.15 & 30.09 & 71.97 & 7.24 \\
\hline $\mathrm{Ru}$ & - & - & - & 5.28 & 5.83 & - & - & 2.11 & 1.30 \\
\hline $\mathrm{Cd}$ & - & - & - & 150.8 & 95.19 & 237.0 & 188.6 & 103.1 & 142.3 \\
\hline $\mathrm{Pb}$ & 140.3 & 32.89 & 1552 & 40.03 & 20.09 & 37.41 & 84.93 & 11.61 & 20.17 \\
\hline Sample & 12976 & HIGO & PHNz & 9997 & 1855 & $91-38$ & 65305 & 65178 & $\mathrm{SH} 9296$ \\
\hline $\mathrm{n}$ & 2 & 2 & 2 & 2 & 2 & 2 & 2 & 2 & 2 \\
\hline $\mathrm{Mg}$ & 11580 & 12450 & 1529 & 1201 & 2902 & 3590 & 6355 & 6803 & 6007 \\
\hline $\mathrm{Si}$ & 23190 & 20860 & 9971 & 21970 & 33000 & 10790 & 7780 & 7876 & 6256 \\
\hline $\mathrm{Ca}$ & 348.7 & 148.4 & 207.9 & 346.7 & 244.8 & 248.6 & 448.9 & 97.19 & 194.2 \\
\hline $\mathrm{Ti}$ & $0.453^{*}$ & $0.187^{*}$ & 2552 & 1099 & 5037 & 4591 & 4609 & 11600 & 9779 \\
\hline $\mathrm{Cr}$ & 51810 & 7070 & $0.738^{*}$ & $0.920^{*}$ & $0.997^{\star}$ & $0.038^{*}$ & 160.6 & 2356 & 6021 \\
\hline $\mathrm{Mn}$ & 109.3 & 962.0 & 6.84 & 14.53 & 23.34 & 5.20 & 4821 & 8.87 & 6.92 \\
\hline $\mathrm{Fe}$ & $0.753^{*}$ & $0.261^{*}$ & $0.327^{*}$ & $0.276^{*}$ & $0.253^{*}$ & $0.471^{*}$ & $0.542^{*}$ & $0.586^{*}$ & $0.964^{*}$ \\
\hline $\mathrm{Ni}$ & 52.09 & 24.58 & 23.69 & 32.71 & 107.8 & 30.05 & 126.8 & 30.40 & 36.47 \\
\hline $\mathrm{Cu}$ & 21800 & 9415 & 436.8 & 605.6 & 482.8 & 605.3 & 477.0 & 1081 & 484.9 \\
\hline $\mathrm{Ga}$ & 8914 & 2805 & 884.4 & 703.2 & 1759 & 1764 & 514.4 & 2684 & 896.2 \\
\hline $\mathrm{Ge}$ & 8025 & 5264 & 850.6 & 732.7 & 771.3 & 988.9 & 3097 & 1492 & 2162 \\
\hline $\mathrm{Rb}$ & 0.56 & 0.42 & 0.17 & 0.51 & 0.10 & 0.24 & 1.21 & 0.33 & 0.44 \\
\hline $\mathrm{Sr}$ & 2.75 & 2.53 & 0.56 & 1.13 & 0.67 & 1.06 & 1.67 & 0.54 & 1.12 \\
\hline$Y$ & 8.21 & 26.19 & 0.40 & 0.19 & 0.31 & 0.63 & 20.32 & 1.53 & 0.67 \\
\hline $\mathrm{Zr}$ & 2634 & 111.7 & 0.38 & 1.76 & 0.45 & 3.01 & 2.01 & 0.38 & 0.91 \\
\hline $\mathrm{Nb}$ & 1649 & 1306 & 0.93 & 2.04 & 2.58 & 0.85 & 1.43 & 2.17 & 0.42 \\
\hline Mo & 350.7 & 75.98 & 19.91 & 22.37 & 11.99 & 8.50 & 5.52 & 5.05 & 8.64 \\
\hline $\mathrm{Ru}$ & 11.69 & 9.02 & 3.89 & 4.05 & 6.17 & 1.70 & 2.27 & 1.71 & 2.06 \\
\hline $\mathrm{Cd}$ & 812.4 & 409.6 & 146.4 & 76.65 & 149.7 & 127.0 & 101.8 & 168.4 & 254.4 \\
\hline $\mathrm{Pb}$ & 42.07 & 54.37 & 27.11 & 30.92 & 33.83 & 30.71 & 57.92 & 23.76 & 26.28 \\
\hline
\end{tabular}

* EPMA analyses concentrations as wt\% oxide; $n$ analyses by SIMS are ppm wt atomic. 


\section{ACKNOWLEDGEMENTS}

Mimi Hill (Univ. Liverpool), Peter Gummer and the Rhonda Mining Corporation, Shirley Wetmore (University of Arizona), Sopemi and the Diamond Trading Company are thanked for supply of samples. Martin Wilding (Arizona State Univ.) is acknowledged for advice on the formulation of standard La-aluminate glass carried out by Jean Tangeman (Containerless Research Inc.). John Craven (Univ. Edinburgh), Rick Hervig (Arizona State Univ.), and Hugh O'Neill are recognized for analytical support. Eric Condliffe is thanked for analytical support and sample assessment. The work presented in this paper was supported by N.E.R.C. postgraduate funding under the supervision of Ben Harte (Univ. Edinburgh) and Jeff Harris (Univ. Glasgow), the N.S.F. (EAR 97-06024, 00-01945), a Visiting Fellowship to the Research School of Earth Sciences, A.N.U. and Diagem for conference attendance to M.T.H. This extended abstract benefited from constructive criticism from Julie Hollis (Univ. Sydney).

\section{REFERENCES}

Davies, R., Griffin, W.L., Pearson, N.J., Andrew, A., Doyle, B.J. and O'Reilly, S.Y. 1999. Diamonds from the Deep: Pipe DO-27, Slave Craton, Canada Proc. VIIth Internat. Kimberlite Conf., Volume I, Gurney, J.J. et al., eds. (Red Roof Design, Cape Town), 148-155n

Drummond, M.S., Wesolowski, D. and Allison, D.T. 1988. Generation, diversification and emplacement of the Rockford Granite, Alabama Appalachians: Mineralogic, Pertrologic, Isotopic ( $\mathrm{C} \& \mathrm{O}$ ) and P-T constraints. $J$. Petrol. 29, 869-897

Harley, S.L. 1993. Sapphirine granulites from the Vestfold Hills, East Antarctica: geochemical and metamorphic evolution. Antarctic Science 5, 389-402

Harley, S.L. 1998. Ultrahigh temperature granulite metamorphism $\left(1050^{\circ} \mathrm{C}, 12 \mathrm{kbar}\right)$ and decompression in garnet $(\mathrm{Mg} 70)$ orthopyroxene-sillimanite gneisses from the Rauer Group, East Antarctica. J. Metamorphic Geol. 16, 541-562

Harte, B., Harris, J.W., Hutchison, M.T., Watt, G.R. and Wilding, M.C. 1999. Lower mantle mineral associations in diamonds from São Luiz, Brazil. In: Fei, Y., Bertka, C., Mysen, B.O. (eds.) Mantle Petrology: Field Observations and High Pressure Experimentation: A Tribute to Francis R. (Joe) Boyd, The Geochemical Society, Houston, Geochem. Soc. Spec. Publ. 6, 125-153

Hutchison, M.T. 1997. Constitution of the deep transition zone and lower mantle shown by diamonds and their inclusions PhD Thesis of the University of Edinburgh, pp. 660 and CDRom

Hutchison, M.T., Cartigny, P. and Harris, J.W. 1999. Carbon and Nitrogen Composition and Cathodoluminescence Characteristics of Transition Zone and Lower Mantle Diamonds from São Luiz, Brazil Proceedings of the VIIth International Kimberlite Conference, Volume I, Gurney, J.J. et al., eds. (Red Roof Design, Cape Town) 372-382

Hutchison, M.T., Hursthouse, M.B. and Light, M.E. 2001. Mineral inclusions in diamonds: associations and chemical distinctions around the $670 \mathrm{~km}$ discontinuity Cont. Mineral. Petrol. 142, 119126

Kerrich, R., Fyfe, W.S., Barnett, R.L., Blair, B.B. and Willmore, L.M. 1987. Corundum, Crmuscovite rocks at O'Briens, Zimbabwe: the conjunction of hydrothermal desilicification and LIL-element enrichment - geochemical and isotopic evidence Contrib. Mineral. Petrol. 95, 481-498

Larrabee, D. M. (1969) Corundum. Mineral and Water Resources, Bull. Arizona Bur. Mines 180, 336337

Nijland, T.G., Liauw, F., Visser, D., Maijer, C. and Senior, A. 1993. Metamorphic Petrology of the Froland corundum-bearing rocks: cooling and uplift history of the Bamble Sector, South Norway. Bull. Norges Geologiske Undersokelse 424, 51-63

Osanai, Y., Hamamoto, T., Kamei, A., Owada, M. and Kagami, H. 1996. High-temperature metamorphism and crustal evolution of the Higo metamorphic terrane, central Kyushu, Japan (in Japanese with English abstr.). In: Tectonics and Metamorphism (SOUBUN, Japan) 113-123

Schreyer, W., Werding, G. and Abraham, K. 1981. Corundum-Fuchsite rocks in greenstone belts of southern africa: petrology, geochemistry, and possible origin J. Petrol. 22, 191-231

Snape, I. and Harley, S.L. 1996. Magmatic history and the high-grade geological evolution of the Vestfold Hills, East Antarctica Terra Antarctica 3, 23-38

Vissor, D. and Senior, A. 1990. Aluminous reaction textures in orthoamphibole-bearing rocks: the pressuretemperature evolution of the high-grade Proterozoic of the Bamble sector, south Norway. J. Metamorphic Geol. 8, 231-246

Watt, G., Harris, J., Harte, B., and Boyd, S. 1994. A highchromium corundum (ruby) inclusion in diamond from the São Luiz alluvial mine, Brazil Mineral. Mag. 58, 490-492

Contact: MT Hutchison, Australian National University

Research School of Earth Sciences, Mills Road, Canberra ACT 0200, Australia, E-mail: mhutchis@lpl.arizona.edu 